Krystyna Gutkowska

Szkota Gtówna Gospodarstwa Wiejskiego w Warszawie

Marlena Piekut

Politechnika Warszawska

\title{
Korzystanie z usług gastronomicznych przez Polaków
}

\author{
THE USE OF CATERING SERVICES BY POLES
}

Celem artykulu była ocena zmian wydatków na ustugi gastronomiczne $w$ polskich gospodarstwach domowych oraz identyfikacja typów gospodarstw domowych przeznaczajacych najwięcej i najmniej na ustugi gastronomii. Materiat źródlowy stanowity indywidualne dane z badania budzetów gospodarstw domowych GUS. Wydatki na gastronomie w gospodarstwach domowych sukcesywnie wzrastaja. Wydatki na ustugi gastronomiczne dość silny zwiazek wykazuja $z$ zawodem wykonywanym przez głowę domu. Większe wydatki na gastronomię występuja w gospodarstwach domowych osób wyżej wyksztatconych oraz wśród gospodarstw domowych jednoosobowych, w rodzinach niepetnych $i$ wśród matżeństw z jednym dzieckiem na utrzymaniu. Istotne znaczenie $w$ wydatkach na usługi gastronomiczne wykazano też względem lokalizacji gospodarstwa domowego.

Slowa kluczowe: determinanty konsumpcji, ustugi, gospodarstwa domowe, gastronomia

\section{Wstęp}

Sektor usług stanowi nieodzowną część codziennego życia większości społeczeństw. Według Dąbrowskiej i wsp. [6] usługi w coraz większym stopniu są twórcami nowych potrzeb i sposobów ich zaspokajania, a także wyznacznikiem poziomu i jakości życia. Zwiększający się udział usług w procesie zaspakajania potrzeb, a więc konsumpcji zwykło się określać mianem serwicyzacji, traktując ją jako jeden z charakterystycznych trendów w konsumpcji.

W gospodarstwach domowych, w szczególności w tych, w których dysponuje się relatywnie dużym funduszem swobodnej decyzji, coraz częściej i w coraz większym zakresie obserwowane jest korzystanie z usług [21], w tym z usług gastronomicznych. Polacy z roku na rok coraz więcej wydają na żywienie poza domem. Modne stało się obchodzenie uroczystości okolicznościowych w jednostkach gastronomicznych, czy podróżowanie, które nierozerwalnie związane jest z żywieniem poza domem. Występują jednak znaczące dysproporcje w wydatkach na gastronomię między różnymi typami gospodarstw domowych, które mają związek $\mathrm{z}$ czynnikami o charakterze ekonomicznym, społeczno-demograficznym, a także lokalizacyjnym. Przyczyn takiego stanu można upatrywać zarówno w odmiennej sytuacji materialnej gospodarstw domowych, jak i innej hierarchii wartości, a w konsekwencji innej hierarchii potrzeb. 
W artykule skoncentrowano uwagę na usługach gastronomicznych i ich udziale w strukturze konsumpcji w polskich gospodarstwach domowych, jak również podjęto próbę oceny zmian wydatków na usługi gastronomiczne oraz czynników wpływających na korzystanie $\mathrm{z}$ gastronomii.

Usługi gastronomiczne zaspokajają potrzeby bytowe konsumentów, a korzystanie z nich może świadczyć o wzroście ich poziomu życia. Obecnie serwicyzacja konsumpcji wyznacza standard życia, a także poziom i nowoczesność konsumpcji [17], stąd też ustalony zakres analizy wydaje się istotny i ważny.

\section{Źródło danych i metodyka badania}

Materiałem badawczym były niepublikowane indywidualne dane z badania budżetów gospodarstw domowych Głównego Urzędu Statystycznego za rok 2012, które obejmowały ponad 37 tys. gospodarstw domowych. Zbiór danych pozyskano w ramach projektu badawczego „Badanie uwarunkowań poziomu konsumpcji w gospodarstwach domowych ze szczególnym uwzględnieniem różnic między województwami". Wykorzystano też wyniki badań wtórnych z zakresu konotowanego tytułem artykułu.

Według GUS wydatki na usługi gastronomiczne obejmują wydatki w restauracjach, kawiarniach, barach, stołówkach, bufetach, ulicznych punktach gastronomicznych, a także w automatach sprzedażowych [11]. Analizowane dane poddano ważeniu.

Do zbadania związków między poziomem wydatków na usługi gastronomiczne a gospodarstwami domowymi wyróżnionymi ze względu na typ biologiczny gospodarstwa domowego, wykształcenie i wykonywany zawód przez głowę domu oraz miejsce lokalizacji gospodarstwa domowego wykorzystano stosunki korelacyjne. Gdy cechy sa nieskorelowane, wartości korelacji są równe 0 , a gdy między badanymi zmiennymi zachodzi zależność funkcyjna - równe są 1. Im wartość korelacji jest bliższa 1, tym zależność korelacyjna jest silniejsza.

Do zbadania istotności zależności między wydatkami na usługi gastronomiczne a gospodarstwami domowymi skategoryzowanymi ze względu na zmienne socjoekonomiczne zastosowano analizę wariacji (test F), natomiast do zbadania różnic pomiędzy poszczególnymi parami zmiennych zastosowano test Scheffe. Test Scheffe wskazuje na istotne statystycznie różnice w porównaniach typu post-hoc i jest najbardziej konserwatywnym testem, czyli stosowanie jego skutkuje najmniejszą ilością istotnych różnic między średnimi [19].

\section{Wyniki badań własnych i dyskusja wyników}

Rozwój sektora gastronomicznego, a także wzrost dochodów rozporządzalnych w gospodarstwach domowych, zmiany demograficzne rodzin (skład, wielkość), zmiany zachowań konsumpcyjnych powodują, że zainteresowanie usługami gastronomicznymi jest coraz większe. W raporcie „Polska na talerzu 2015” [16] wykazano, że 15\% Polaków regularnie jada poza domem, $35 \%$ względnie często, a $32 \%$ jada poza domem rzadziej niż raz na 3 miesiące. Wskazuje się, że żywienie poza domem ma przede wszystkim kontekst społeczny, gdyż głównym powodem korzystania z usług gastronomicznych jest chęć spotkania się ze znajomymi, a dopiero w następnej kolejności wygoda i oszczędność czasu. 
Do 2006 roku liczba placówek świadczących usługi żywieniowe wzrastała w szybkim tempie, jednakże w latach 2006-2013 obserwuje się tendencję spadkową. Przyczyną przyhamowania rozwoju było pogorszenie ogólnej sytuacji gospodarczej, która dotknęła różne sektory gospodarki [8]. Należy jednak zaznaczyć, iż przychody z działalności gastronomicznej $\mathrm{z}$ roku na rok wzrastają, co świadczy o wciąż systematycznie rosnącym popycie wśród konsumentów. Według Frontczaka prognozy na lata kolejne są optymistyczne i rynek polski ocenia się jako jeszcze nienasycony i o dużym potencjale.

W raporcie z 2014 roku Rynek gastronomiczny w Polsce spośród rozmaitych rodzajów lokali, Polacy najchętniej wybierają restauracje, pizzerie oraz placówki typu fast-food i bary z lokalną kuchnią, przy czym zdecydowanie częściej z restauracji fastfood korzystają mężczyźni.

W polskich gospodarstwach domowych wydatki na gastronomię i zakwaterowanie w przeliczeniu na jedną osobę między rokiem 2000 a 2014 zwiększyły się 5,4-krotnie, tj. z ponad $8 \mathrm{zł}$ do ponad $45 \mathrm{zł}$, podczas gdy, wydatki ogółem wzrosły 0,8-krotnie na osobę z blisko 600 zł do prawie 1079 zł. Udział wydatków na usługi gastronomiczne i noclegowe w wydatkach ogółem też uległ wzrostowi z 1,4\% w 2000 roku do 4,2\% w 2014 roku [4].

Mimo relatywnie dużego wzrostu wydatków na gastronomię, stanowią one wciąż jeszcze w strukturze wydatków Polaków znikomy odsetek w porównaniu do innych mieszkańców UE, w szczególności Europy Zachodniej i Północnej. W 2012 roku najwyższe wydatki na gastronomię charakteryzowały gospodarstwa domowe Hiszpanów - 14,9\% wydatków ogółem, a następnie Irlandczyków - 11,8\% oraz Maltańczyków $11,0 \%$. Średnio w UE-28 wydatki na gastronomię wynosiły $7 \%$, a w polskich gospodarstwach domowych $2,1 \%$ i był to najniższy udział wśród krajów UE [7]. Generalnie w krajach Europy Środkowo-Wschodniej, w tym także w Polsce, obserwowana jest większa dynamika wzrostu wydatków na usługi gastronomiczne niż w innych krajach UE [14], co wskazuje na postępujący proces ujednolicania struktur wydatków konsumpcyjnych w UE.

Intensywny rozwój rynku usług gastronomicznych w krajach Europy ŚrodkowoWschodniej obserwowany jest już od wielu lat, kiedy to przejście od gospodarki centralnie planowanej do opartej na regułach rynkowych spowodowało proces prywatyzacji podmiotów gospodarczych. Początek wzrostu sektora gastronomii w Polsce rozpoczął się wraz z wprowadzeniem ustawy dotyczącej swobody podejmowania działalności gospodarczej.

W dostępie do tego rynku występują jednak znaczne dysproporcje. Usługi gastronomiczne to potrzeby wyższego rzędu, a zatem większego ich poziomu można się spodziewać w gospodarstwach domowych z korzystniejszą sytuacją materialną. Choć wskazuje się, że wydatki na usługi gastronomiczne zależne są od wielu zmiennych charakteryzujących gospodarstwa domowe, to dochód rozporządzalny na osobę jest jednym z najsilniejszych czynników determinujących korzystanie z tego rodzaju usług $[10,15]$. W Polsce nierówności w dochodach zmniejszają się, o czym świadczy m.in. fakt, że wskaźnik Giniego w 2005 roku wyniósł 35,6 (w skali 0-100), podczas gdy w 2014 roku - 30,8. Nadal jednak występujące relatywnie wysokie dysproporcje w dochodach wywierają wpływ na dostępność usług dla poszczególnych typów gospodarstw domowych. 
$\mathrm{Na}$ zachowania konsumentów obok dochodów mają wpływ również cechy społeczno-demograficzne gospodarstw domowych. I tak np. relatywnie silną determinantą wydatków na gastronomię okazał się poziom wykształcenia. Współczynnik korelacji między wydatkami na usługi gastronomiczne a gospodarstwami domowymi wyróżnionymi ze względu na poziom wykształcenia głowy domu wyniósł 0,184 . Wykazano istotne statystycznie różnice $(\mathrm{p}<0,05)$ pomiędzy wszystkimi typami gospodarstw domowych wyróżnionych ze względu na poziom wykształcenia głowy domu a wydatkami na gastronomię (test Scheffe).

Wydatki na usługi gastronomiczne w gospodarstwach domowych reprezentowanych przez osoby z co najwyżej gimnazjalnym poziomem wykształcenia wynosiły 13 zł na osobę, co stanowiło 1,7\% wydatków ogółem. W gospodarstwach domowych z wyższym poziomem wykształceniem głowy domu wydatki te pochłaniały ponad $55 \mathrm{zł}$ na osobę, a w strukturze wydatków - 3,5\% wydatków ogółem, czyli wydatki na usługi gastronomiczne $\mathrm{w}$ gospodarstwach domowych prowadzonych przez osoby $z$ wyższym wykształceniem były 4,2-krotnie większe niż w gospodarstwach domowych reprezentowanych przez osoby z co najwyżej gimnazjalnym poziomem wykształcenia (Wykres 1)

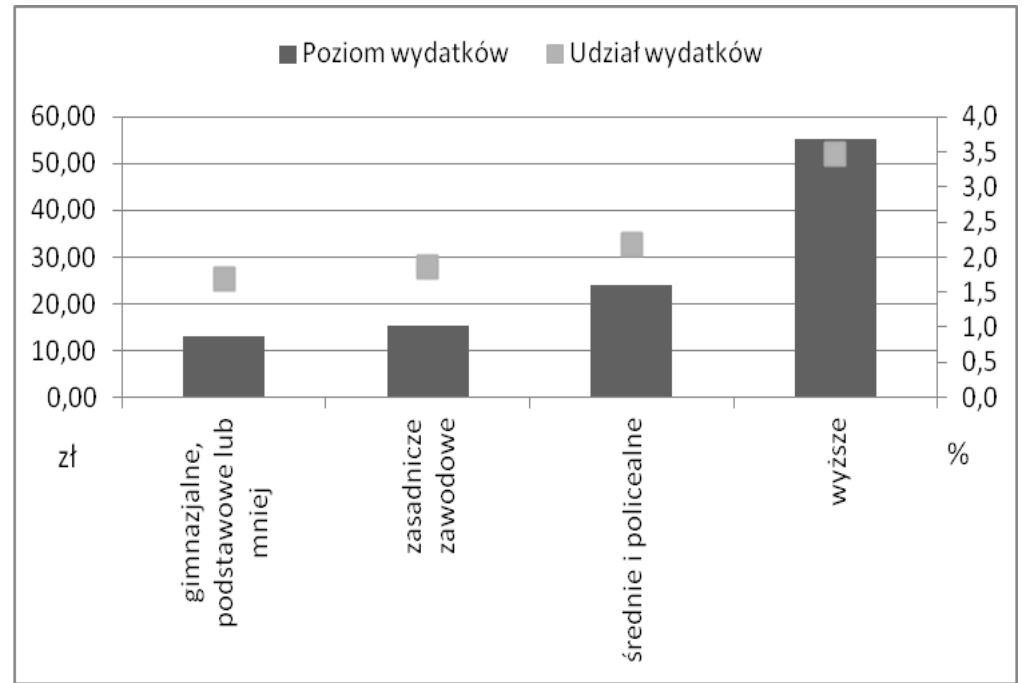

Wykres 1. Miesięczne wydatki na usługi gastronomiczne w gospodarstwach domowych prowadzonych przez osoby $\mathrm{z}$ różnym poziomem wykształcenia w $2012 \mathrm{r}$.

Źródło: obliczenia własne na podstawie indywidualnych danych z badania budżetów gospodarstw domowych GUS

Wzrost wydatków na usługi gastronomiczne wraz ze wzrostem poziomu wykształcenia zaobserwowano też $w$ innych badaniach [2, 22], co jest tłumaczone wyższymi dochodami w gospodarstwach osób lepiej wykształconych oraz faktem częstszego uczestnictwa tych osób w wydarzeniach społecznych.

$\mathrm{Z}$ badań [3, 16] wynika, że na korzystanie z placówek gastronomicznych niebagatelny wpływ wywiera internet, zarówno do wyszukiwania najlepszych miejsc na 
obiad, jak i planowania wspólnych wyjść towarzyskich do lokalów gastronomicznych. Według danych z raportu „Polska na talerzu” [16] ponad połowa ankietowanych wskazała internet, jako główne źródło informacji o lokalach gastronomicznych. Według danych „Wykorzystanie technik telekomunikacyjnych $w$ gospodarstwach domowych $i$ przedsiębiorstwach w 2014 roku" [20] ponad 97\% osób z wyższym poziomem wykształcenia regularnie korzystało $\mathrm{z}$ internetu, około $70 \%$ ankietowanych ze średnim wykształceniem i około połowa respondentów z niższym wykształceniem. Internet jest więc cennym narzędziem promocji jednostek gastronomicznych i źródłem informacji na ich temat.

Silniejszą determinantą wydatków na usługi gastronomiczne od wykształcenia okazał się zawód wykonywany przez głowę domu. Współczynnik korelacji wyniósł w tym przypadku 0,210. Zmienna „zawód głowy domu” istotnie statystycznie $(\mathrm{p}<0,05)$ różnicowała poziomy wydatków na usługi gastronomiczne, aczkolwiek wyniki testu Scheffe wskazały, że nie między wszystkim typami gospodarstw domowych były istotne statystycznie różnice.

Najwięcej na usługi gastronomiczne przeznaczali przedstawiciele władz publicznych, wyżsi urzędnicy oraz dyrektorzy, tj. 101 zł na osobę, co stanowiło 4,3\% wydatków ogółem, co wynika zapewne z charakteru pracy tych osób. Na drugim miejscu pod względem wielkości wydatków na usługi gastronomiczne znaleźli się specjaliści do spraw technologii informacyjno-telekomunikacyjnych - blisko $87 \mathrm{zł}$ na osobę $(4,7 \%$ wydatków ogółem), a następnie specjaliści z dziedziny prawa, dziedzin społecznych i kulturalnych - ponad 84 zł na osobę (4,3\% wydatków ogółem). Relatywnie wysoki odsetek wydatków na usługi gastronomiczne przeznaczano w gospodarstwach domowych, w których głową domu byli szeregowi oficerowie, a wydatki na te usługi pochłaniały $6,7 \%$ wydatków ogółem (ponad 81 zł na osobę). Najniższe poziomy wydatków na usługi gastronomiczne zaobserwowano w gospodarstwach domowych sprzedawców ulicznych i pracowników świadczących usługi na ulicach, w gospodarstwach tych przeznaczano około 3 zł na osobę, co stanowiło $0,5 \%$ wydatków ogółem. Usługi gastronomiczne pochłaniały na osobę od 8 zł do 9 zł w gospodarstwach domowych rolników i rybaków, co stanowiło około $1 \%$ wydatków ogółem. Nieco więcej, choć relatywnie mało $\mathrm{w}$ porównaniu z innymi zawodami, na żywienie poza domem przeznaczali robotnicy $\mathrm{w}$ przetwórstwie spożywczym, obróbce drewna, rolnictwie, leśnictwie, rybołówstwie wydając na osobę $10 \mathrm{zl}-11$ zł (1,4\%-1,9\% wydatków ogółem). Niskie dochody oraz specyfika pracy zapewne mają wpływ na skalę korzystania z usług żywieniowych.

Wykształcenie oraz profesja głowy domu to istotne statystycznie cechy gospodarstw domowych różnicujące poziom wydatków na usługi gastronomiczne. Kolejną istotnie statystyczną determinantą mającą związek $\mathrm{z}$ wydatkami na usługi gastronomiczne okazał się typ biologiczny gospodarstwa domowego. Najwyższy poziom wydatków na usługi gastronomiczne odnotowano w jednoosobowych gospodarstwach domowych - 62 zł na osobę (3,7\% wydatków ogółem). Niższe wydatki niż w jednoosobowych gospodarstwach domowych odnotowano w rodzinach niepełnych, to znaczy ojców samotnie wychowujących dzieci - 46 zł oraz matek samotnie wychowujących dzieci - 38 zł. Wydatki na usługi gastronomiczne w rodzinach niepełnych pochłaniały jednak większe części budżetów domowych niż w jednoosobowych gospodarstwach, tj. w przypadku ojców samotnie wychowujących 
dzieci - 4,8\%, a w przypadku matek samotnie wychowujących dzieci - 4,0\%. Najmniej na usługi gastronomiczne przeznaczano $\mathrm{w}$ gospodarstwach domowych innych osób $\mathrm{z}$ dziećmi na utrzymaniu - około 8 zł (1,3\% wydatków ogółem) oraz małżeństw z przynajmniej jednym dzieckiem na utrzymaniu i innymi osobami - 11 zł $(1,5 \%$ wydatków ogółem) (wykres 2).

Typy gospodarstw domowych: I - gospodarstwa domowe bez dzieci na utrzymaniu; II gospodarstwa domowe małżeństw z 1 dzieckiem na utrzymaniu, III - gospodarstwa domowe małżeństw z 2 dzieci na utrzymaniu, IV - gospodarstwa domowe małżeństw z 3 dzieci na utrzymaniu, $\mathrm{V}$ - gospodarstwa domowe małżeństw z 4 i większą liczbą dzieci na utrzymaniu, VI - gospodarstwa domowe samotnych matek z dziećmi na utrzymaniu, VII - gospodarstwa domowe samotnych ojców z dziećmi na utrzymaniu, VIII gospodarstwa domowe matek $\mathrm{z}$ dziećmi na utrzymaniu i innymi osobami, IX gospodarstwa domowe ojców z dziećmi na utrzymaniu i innymi osobami, X gospodarstwa domowe małżeństw z przynajmniej 1 dzieckiem na utrzymaniu i innymi osobami, XI - gospodarstwa domowe jednoosobowe, XII - gospodarstwa domowe innych osób z dziećmi na utrzymaniu, XIII - pozostałe gospodarstwa domowe.

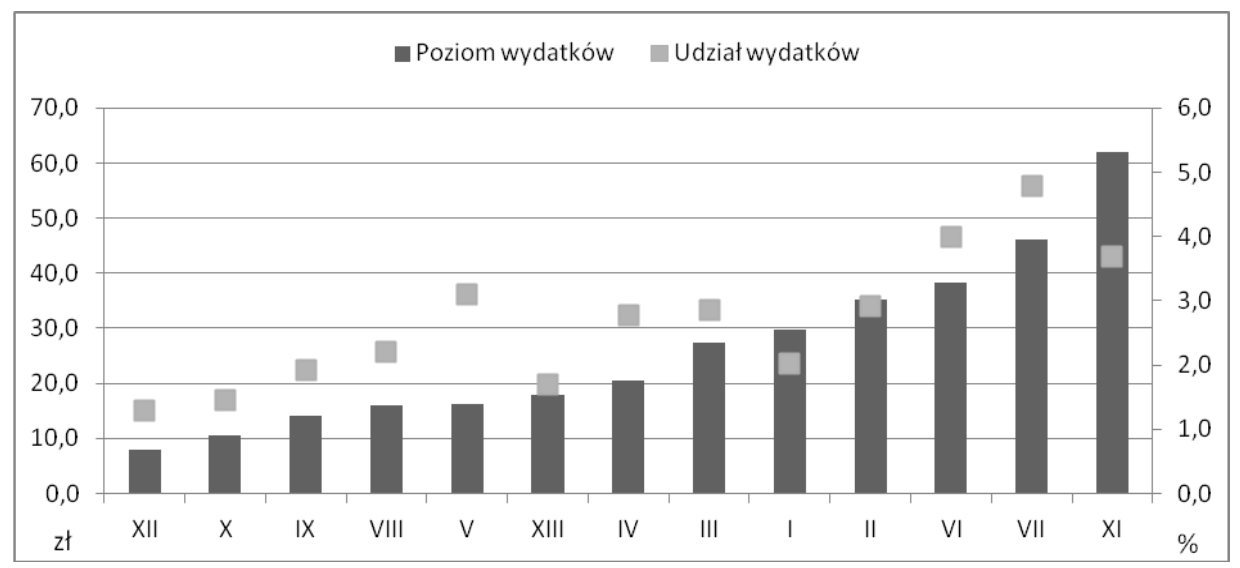

Wykres 2. Miesięczne wydatki na usługi gastronomiczne w różnych typach biologicznych gospodarstw domowych w $2012 \mathrm{r}$.

Źródło: obliczenia własne na podstawie indywidualnych danych z badania budżetów gospodarstw domowych GUS

W innych badaniach [3] wykazano, że w gospodarstwach domowych z dziećmi na utrzymaniu przeznacza się więcej na żywienie poza domem niż w gospodarstwach domowych bezdzietnych, co częściowo też potwierdza niniejsza analiza. Większe wydatki na gastronomię $w$ gospodarstwach domowych $\mathrm{z}$ dziećmi na utrzymaniu mogą być konsekwencją korzystania przez dzieci z usług fast-food, na co wskazują badania Akbay Tiryaki, Gül [1] oraz Bozoglu, Bilgic, Yen, Huang [3].

$\mathrm{Z}$ drugiej strony $\mathrm{w}$ badaniach $[5,9,12]$ wykazano, że fakt posiadania dzieci na utrzymaniu negatywnie wpływa na wydatki na gastronomię, co wskazuje na oddziaływanie jednoczesne innych zmiennych. 
Istotne statystycznie różnice w poziomie wydatków na usługi gastronomiczne zauważono także w gospodarstwach domowych położonych w różnych województwach oraz na obszarach o różnym stopniu urbanizacji terenu. Współczynnik korelacji między wydatkami na usługi gastronomiczne a gospodarstwami domowymi podzielonymi ze względu na lokalizację w określonym województwie wyniósł 0,105 , natomiast ze względu na lokalizację w odniesieniu do stopnia urbanizacji obszaru 0,135 .

Największy poziom wydatków na osobę na usługi gastronomiczne odnotowano w gospodarstwach domowych z województwa mazowieckiego - ponad $42 \mathrm{zl}$, a następnie z dolnośląskiego - $34 \mathrm{zł}$ oraz zachodniopomorskiego - 33 zł. W województwach tych odnotowano też największe udziały wydatków na usługi gastronomiczne $-3,0-3,1 \%$ wydatków ogółem. Najmniejsze wydatki na usługi gastronomiczne były w województwach: podkarpackim, warmińsko-mazurskim, lubelskim i kujawskopomorskim - około $15 \mathrm{zł}$ na osobę, co stanowiło 1,6-1,7\% wydatków ogółem, a więc w województwach o mniej korzystnych zmiennych makroekonomicznych (wykres 3 ).

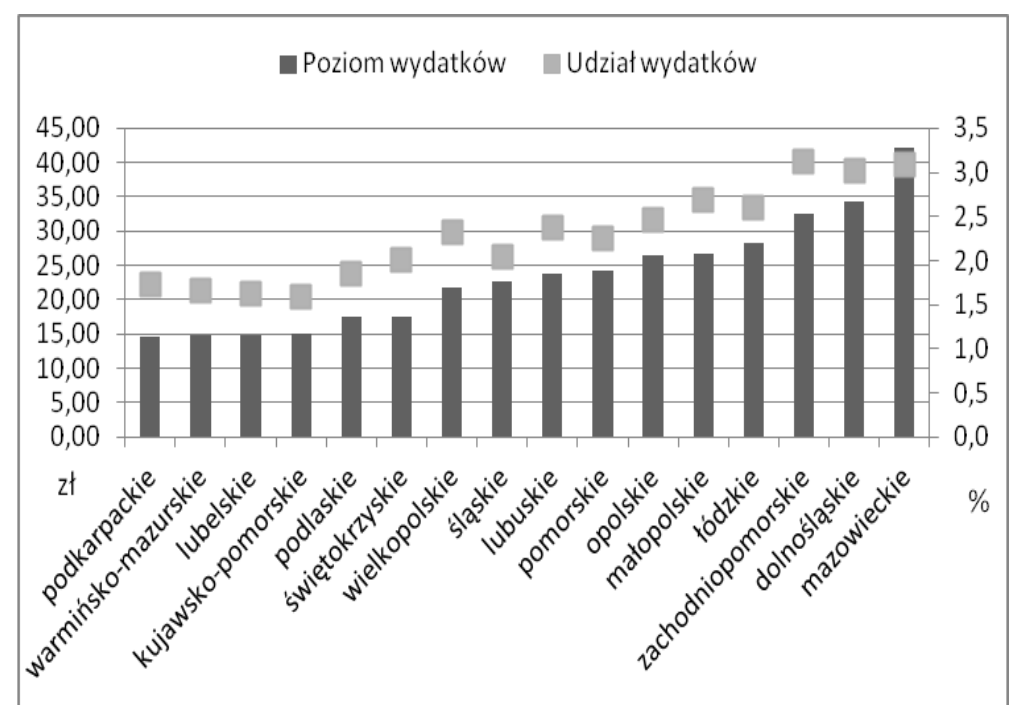

Wykres 3. Miesięczne wydatki na usługi gastronomiczne w gospodarstwach domowych zlokalizowanych w różnych województwach w 2012 r.

Źródło: obliczenia własne na podstawie indywidualnych danych z badania budżetów gospodarstw domowych GUS

Wykazano [18], że istnieją znaczne różnice w sytuacji dochodowej między gospodarstwami domowymi z różnych województw. W raporcie Diagnoza społeczna 2013 gospodarstwa domowe o relatywnie najlepszej sytuacji dochodowej były zlokalizowane między innymi w województwach mazowieckim i zachodniopomorskim, a o wyraźnie słabszej sytuacji dochodowej w województwach warmińsko-mazurskim i lubelskim. W wymienionych województwach wydatki na gastronomię w gospodarstwach domowych też znajdowały się na dwóch przeciwległych końcach skali.

Zauważono, że im obszar lokalizacji gospodarstwa domowego cechował mniejszy wskaźnik zaludnienia, tym wydatki na usługi gastronomiczne były mniejsze. 
Na obszarach gęsto zaludnionych wydatki na gastronomię były 2,8-krotnie większe w porównaniu do obszarów o słabym zaludnieniu. W strukturze wydatków usługi gastronomiczne $\mathrm{w}$ gospodarstwach domowych zlokalizowanych na obszarach gęsto zaludnionych pochłaniały $3,1 \%$, a na obszarach o słabym zaludnieniu - 1,6\% (wykres 4).

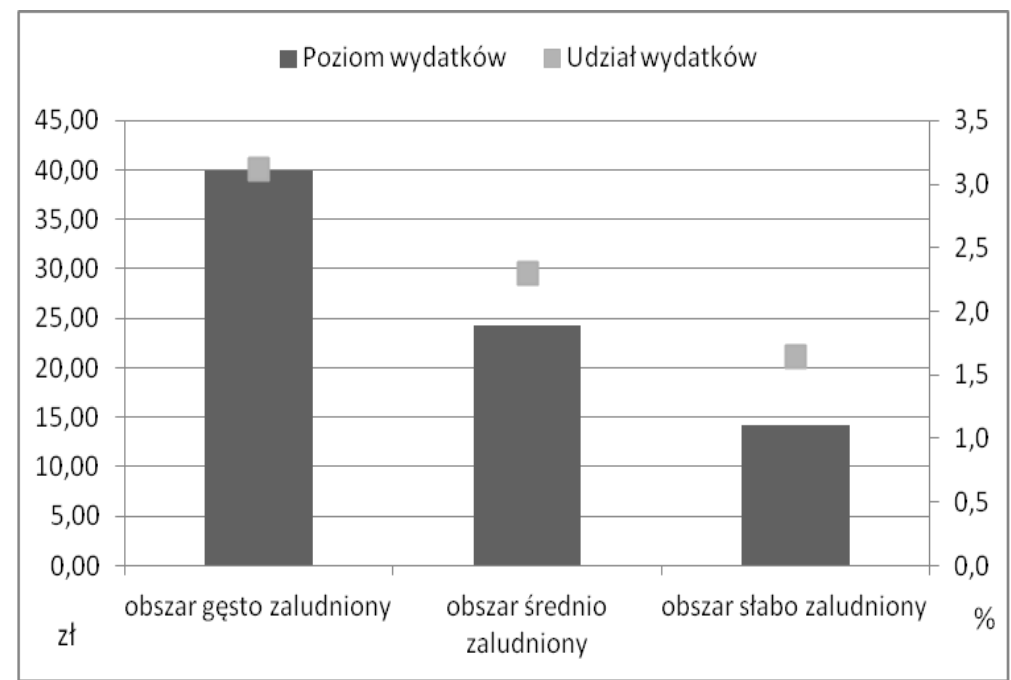

Wykres 4. Miesięczne wydatki na usługi gastronomiczne w gospodarstwach domowych zlokalizowanych na obszarach o różnym stopniu urbanizacji obszaru w 2012 r.

Źródło: obliczenia własne na podstawie indywidualnych danych z badania budżetów gospodarstw domowych GUS

W innych badaniach [15] wykazano, że im była większa jednostka osadnicza mierzona liczbą mieszkańców, tym były większe wydatki na gastronomię i zakwaterowanie, i tym wydatki te pochłaniały większą część budżetów domowych. W gospodarstwach domowych wiejskich, a w szczególności powiązanych z rolnictwem [13] obserwowano mniejsze wydatki na żywienie poza domem. Korzystanie z usług gastronomicznych niejednokrotnie wiąże się z wyjazdami turystycznymi [8]. W badaniu Diagnoza Społeczna 2013 wykazano, że to właśnie mieszkańcy wsi, czyli obszarów o słabym zaludnieniu, byli najczęściej zmuszeni do rezygnacji z wyjazdów turystycznych. W przypadku wiejskich gospodarstw domowych zmuszonych było do rezygnacji z wyjazdów turystycznych z powodów finansowych: 59\% osób dorosłych oraz $49 \%$ dzieci i młodzieży. Choć obok problemów finansowych, przyczyn mniejszych wydatków na gastronomię i inne usługi związane z zagospodarowywaniem wolnego czasu, Piekut i Gutkowska [15] upatrują w braku wolnego czasu (praca w gospodarstwie rolnym) oraz odmiennej hierarchii wartości w wiejskich gospodarstwach domowych.

\section{Zakończenie}

W Polsce, podobnie jak i w innych krajach UE, wydatki na gastronomię w gospodarstwach domowych sukcesywnie wzrastają, choć nie we wszystkich z taką samą intensywnością. Wydatki na usługi gastronomiczne zależą od wielu zmiennych, w tym 
dość silny związek wykazują z zawodem wykonywanym przez głowę domu. Charakter wykonywanej pracy, specyfika danego zawodu niejednokrotnie determinują fakt organizacji żywienia w domu bądź poza domem. Większe wydatki na gastronomię występują w gospodarstwach domowych osób wyżej wykształconych, co wiąże się z tym, że wyższy poziom wykształcenia sprzyja uzyskiwaniu wyższych dochodów w tych gospodarstwach oraz uczestnictwu osób legitymujących się wyższym wykształceniem w większej ilości wydarzeń społecznych.

Większe wydatki na usługi gastronomiczne zaobserwowano też wśród gospodarstw domowych jednoosobowych oraz $\mathrm{w}$ rodzinach niepełnych (matek lub ojców samotnie wychowujących dzieci), a także wśród małżeństw z jednym dzieckiem na utrzymaniu.

Istotne znaczenie w wydatkach na usługi gastronomiczne wykazano względem lokalizacji gospodarstwa domowego. Największe wydatki na gastronomię dotyczyły gospodarstw domowych zlokalizowanych w województwach mazowieckim, dolnośląskim i zachodniopomorskim. Warto jednak pamiętać, że omawiane wydatki są zdecydowanie większe na obszarach o gęstym zaludnieniu niż na obszarach wiejskich.

Tym samym dowiedziono znaczących różnic w wydatkach na usługi gastronomiczne pomiędzy gospodarstwami domowymi o odmiennych charakterystykach socjodemograficznych i ekonomicznych jak również różnym ich udziale w wydatkach ogółem. Można przypuszczać, że różnice te są znamienne dla odmiennych stylów życia charakteryzujących głowy tych gospodarstw, jak również uznawanej przez nich hierarchii wartości.

\section{Literatura}

Akbay, C., Tiryaki, G.Y., Gül, A., 2007. "Consumer characteristics influencing fast food consumption in Turkey". Food Control 18 (8): 904-913.

Angulo, A.M., Gil, J.M., Mur, J., 2007. "Spanish demand for food away from home: analysis of panel data". Journal of Agricultural Economics 58 (2): 289-307.

Bozoglu, M., Bilgic, A., Yen, S. T., \& Huang, C. L. 2013."Household food expenditure at home and away from home in Turkey." Selected paper prepared for presentation at the Agricultural and Applied Economics Association (AAEA) and CAES joint Annual meeting, Washington DC.

Budżety gospodarstw domowych w 2014 roku. 2015. Warszawa: GUS.

Chang, H.H., Yen, S.T., 2010. "Off-farm employment and food expenditures at home and away from home". European Review of Agricultural Economics 37 (4): 523-551.

Dąbrowska A., Gutkowska K., Janoś-Kresło M., Ozimek I. 2010. Serwicyzacja konsumpcji w polskich gospodarstwach domowych. Uwarunkowania i tendencje. Warszawa: Difin.

Final consumption expenditure of households by consumption purpose - COICOP 3 digit aggregates at current prices [nama_co3_c] Eurostat http://ec.europa.eu/eurostat/data/database $(01.10 .2015)$

Gheribi, E. 2014. „Struktura popytu na usługi przedsiębiorstw gastronomicznych w czasie wyjazdów turystycznych. Zeszyty Naukowe. Turystyka i Rekreacja, (2 (14)): 63-79.

Jensen, H.H., Yen, S.T., 1996. „Food expenditures away from home by type of meal”. Canadian Journal of Agricultural Economics 44 (1): 67-80.

Liu, M., Kasteridis, P., Yen, S. T. 2013. "Breakfast, lunch, and dinner expenditures away from home in the United States". Food Policy, 38: 156-164.

Metodologia badania budżetów gospodarstw domowych, 2011, Departament Warunków Życia, Warszawa: GUS. 
Mihalopoulos, V.G., Demoussis, M.P., 2001. "Greek household consumption of food away from home: a microeconometric approach". European Review of Agricultural Economics 28 (4): 421-432.

Ogundari, K., Aladejimokun, A. O., Arifalo, S. F. 2015. "Household demand for food away from home (fafh) in Nigeria: the role of education". The Journal of Developing Areas, 49(2): 247-262.

Piekut M (2015). Konsument i konsumpcja w Unii Europejskiej. Płock: Kolegium Nauk Ekonomicznych i Społecznych Politechniki Warszawskiej, Oficyna Wydawnicza Politechniki Warszawskiej.

Piekut M., Gutkowska K 2013. „Uwarunkowania poziomu wydatków na turystykę i rekreację oraz usługi gastronomiczne i zakwaterowania w wiejskich gospodarstwach domowych". Marketing i Rynek: 527-539.

Polska na talerzu 2015. Raport firmy Makro Cash \& Cary. http://www.grupaiqs.pl/wpcontent/uploads/2015/04/raport_polska_na_talerzu_2015.pdf

Radziukiewicz, M. 2012. „Zmiany sytuacji dochodowej a wydatki na usługi w polskich gospodarstwach domowych". Konsumpcja i Rozwój, (1 (2)): 101-116.

Strzelecki, P., Saczuk, K., Grabowska, I., Kotowska, I.E. 2013. Warunki życia gospodarstw domowych. Rynek pracy. Diagnoza Społeczna 2013 Warunki i Jakość Życia Polaków - Raport. [Special issue]. Contemporary Economics, 7, 122-152 DOI: 10.5709/ce.1897-9254.105

Wątroba, J. 2004. Analiza wariancji. Materiały kursowe. Kraków: Statsoft.

Wykorzystanie technik telekomunikacyjnych w gospodarstwach domowych i przedsiębiorstwach w 2014 roku, Warszawa: GUS.

Zalega T., 2008. Konsumpcja w gospodarstwach domowych o niepewnych dochodach. Warszawa: Wydawnictwo Uniwersytetu Warszawskiego.

Zan, H., Fan, J., 2010. „Cohort effects of household expenditures on food away from home”. The Journal of Consumer Affairs 44 (1), 213-233.

\section{Summary}

The aim of the article was to evaluate changes in spending on catering services in Polish households and identify the types of households with the largest and smallest expenditure on catering services. The research material consisted of individual data from the household budget survey conducted by the CSO. Expenditure on catering to households gradually increase.

Key words: determinants of consumption, services, households, catering

Informacja o autorach:

prof. dr hab. Krystyna Gutkowska

Wydział Nauk o Żywieniu Człowieka i Konsumpcji

Szkoła Główna Gospodarstwa Wiejskiego w Warszawie

e-mail: krystyna_gutkowska@sggw.pl

dr inż. Marlena Piekut

Kolegium Nauk Ekonomicznych i Społecznych

Politechnika Warszawska

e-mail: mpiekut@op.pl 